\title{
EFFECTS OF DIFFERENT EPIDURAL ANALGESIC COMPOSITIONS ON POSTOPERATIVE PAIN RELIEF AND SYSTEMIC RESPONSE TO SURGERY
}

\author{
Iveta Golubovska*, Pēteris Studers*, Inta Jaunalksne**, and Indulis Vanags*** \\ * Hospital of Traumatology and Orthopaedics, Duntes iela 12/22, Rīga, LV-1005, LATVIA; \\ e-mail: ivetagolubovska@gmail.com \\ ** Clinical Immunology Centre, Rīga Stradiṇš Hospital, Pilsoṇu 13, Rĩga, LV-1010, LATVIA \\ *** Department of Anaesthesiology and Reanimatology, Rīga Stradiṇš University, Dzirciema iela 16, Rīga, LV-1007, LATVIA \\ Communicated by Jānis Gardovskis
}

\begin{abstract}
Despite many achievements during the last decade, postoperative pain remains the dominant complaint after major surgery and has great potential to be influenced by the anaesthesiologist. Reports suggest that short-term effective anaesthesia and analgesia can have long-lasting beneficial effects on recovery from surgery. The aim of our study is to compare the effect of epidural analgesia, using different compositions, including glucocorticoids (methylprednisolone), and habitual composition of bupivacaine-morphine, in regard to analgesic and anti-inflammatory properties. A total of 129 patients participated in the study in four different treatment groups: patients from Group I received glucocorticoid methylprednisolone succinate and long-acting opioid morphine hydrochloride, Group II received local anaesthetic bupivacaine hydrochloride and morphine hydrochloride, Group III received methylprednisolone succinate and short-acting opioid fentanyl, and Group IV received glucocorticoid methylprednisolone succinate. We obtained good analgesic profiles in all groups. However, significantly better results were achieved using the combination of methylprednisolone and morphine. Epidural methylprednisolone in dose $80 \mathrm{mg} / 24 \mathrm{~h}$ is more effective, compared to the conventional local anaesthetics-opioid composition, when administered as a part of multimodal preventive postoperative analgesia after major joint replacement surgery. Epidural methylprednisolone has a reliable anti-inflammatory and immunomodulatory potential. It attenuates profiles of acute inflammatory response markers as Interleukin-6 and C-reactive protein and stress hormone cortisol. The novelty of this study was application of epidural glucocorticoids for acute postoperative pain relief as part of daily perioperative care. By developing studies on anti-inflammatory and immunomodulatory properties of glucocorticoids, we expect to improve patient rehabilitation in the postoperative period.
\end{abstract}

Key words: glucocorticoids, methylprednisolone, epidural, postoperative analgesia.

\section{INTRODUCTION}

Despite increasing understanding of pain mechanisms and ongoing research in pain therapy, improved postoperative analgesia is a challenge for anaesthesiologists and every person involved in patient care postoperatively. The efficacy of postoperative pain therapy after major joint replacement surgery is one of the most important factors in functional outcome. Good postoperative analgesia is associated with less postoperative physiological disturbances and improvement in postoperative morbidity and rehabilitation. This paper proposes the epidural application of glucocorticoids as a component of balanced preventive multimodal analgesia for acute postoperative pain relief after knee replacement surgery. An increasing number of publications concerning the use of steroids in acute pain relief has appeared in recent years. The development of adrenocortical physiology and pharmacology has advanced exogenous glucocorticoids to become one of the most widely used classes of drugs in clinical medicine (Schimmer et al., 1996). Glucocorticoids have powerful anti-inflammatory characteristics (Ontjes et al., 1995; Ferreira et al., 1997; Barnes et al., 1998). In the last years, several theories about the genomic effects of glucocorticoids have been developed. The inhibition of inflammation involves decreased stability of messenger ribonucleic acid (mRNA) for the genes of inflammatory proteins, such as vascular endothelial growth factor and cyclooxygenase (COX)-2. Glucocorticoid-induced effects that require protein synthesis have about two hours latency of onset; therefore, to have advantages in anti-inflammatory and pain reductive effects, it seems to be necessary to inject glucocorticoids preoperatively. At the same time, there are reports of rapid onset of analgesic and antihyperalgesic effects of glucocorticoids (Romunstad et al., 2004). It is now accepted that 
glucocorticoids, in addition to the traditional genomic effects which take hours, show rapid effects by acting on membrane receptors (Falkenstein et al., 2000). These rapid nongenomic effects of glucocorticoids are due, at least in part, to decreased glutamate release and increased release of $\gamma$-aminobutyric acid and endocannabinnoids (Di et al., 2005). Recent work suggests that glucocorticoids can have rapid effects on inflammation that are not mediated by changes in gene expression. The best described nongenomic mechanism involves the activation of endothelial nitric oxide synthetase (eNOS) (Hafezi-Moghadam et al., 2002). Small proteins called cytokines have a major role in the inflammatory response to surgery, trauma and pain mechanisms. They have local effect of mediating and maintaining the inflammatory response to tissue injury and they also initiate some of the systemic changes that may occur. The main cytokines released are interleukin-1 (IL-1), tumour necrosing factor (TNF- $\alpha$ ) and interleukin-6 (IL-6); they are responsible for inducing the systemic changes known as the acute phase response. Administration of glucocorticoids after incision suppresses the release of proinflammatory cytokines. Varying doses of glucocorticoids do not lead simply to varying degrees of inflammation suppression; considerably more, they can exert a full range of effects from permissive to stimulatory to suppressive (Yeager et al., 2004).

Glucocorticoids are efficacious in perioperative management and particularly in postoperative pain relief as adjuvant analgesics (Watanabe et al., 1994). Glucocorticoids have potent anti-inflammatory effects and reduce pain and swelling after oral operations (Skjelberd et al., 1982), orthopaedic and spinal operations (Holte et al., 2002), laparoscopic (Bisgaard et al., 2003), major abdominal (Schulze et al., 1992, 1998) and artroscopic procedures (Kizilkaya et al., 2005) as well as after lumbar disc surgery (Lavyne et al., 1992; Glasser et al., 1993; Langmayr et al., 1995). There are many publications supporting high doses of intravenous glucocorticoids during major cardiac, abdominal and orthopaedic surgery (Nagelshmidt et al., 1999; Sauerland et al., 2000; Yeager et al., 2004, 2005), which decrease stress response to major surgery. We have found recent observational studies (Marinangeli et al., 2002; Gilron et al., 2004; Salerno et al., 2006, Kehlet, 2007) suggesting wider application of glucocorticoids for postoperative pain relief. Findings in experimental pain models (Romunstad et al., 2004; Stubhaug et al., 2007) help to understand the research results on the effects of methylprednisolone on reduction of pain, postoperative nausea and vomiting, fatigue and late wound hyperesthesia, as well as sustained analgesic effect and reduced opioid requirements for 1-3 days after surgery (Romunstad et al., 2004, 2006).

Patients who have a herniated disk, spinal stenosis or failed back surgery may benefit from epidural steroid injection with methylprednisolone acetate (Manchikanti et al., 2002; Singh et al., 2002). Reports on thousands of patients indicate that epidural glucocorticoid injections are relatively straightforward and safe in the treatment of back pain (Carette et al., 1997).

Anaesthesiologists began to use steroids epidurally mostly for backache treatment common after surgery or epidural needle insertion. Soon after, they discovered significant reduction in postoperative analgesia requirements. McNeil et al. (1995) administered epidurally separately saline solution, morphine, methylprednisolone and a combination of morphine and methylprednisolone for pain reduction after spinal stenosis surgery or herniated intervertebral disc. Wang et al. (1998) gave dexametasone epidurally after muiltiple epidural needle insertion. The severity and duration of postepidural backache also significantly decreased in those patients. Since patients complained about back pain after surgical interventions - mostly related to bad positioning or pre-existing discogenic disease-on the supposition that postoperative pain should be treated preventively, patients received $1 \mathrm{mg}$ morphine with $80 \mathrm{mg}$ of methylprednisolone epidurally directly after surgery (Joos et al., 1993). Preoperative epidural administration of dexamethasone 5 $\mathrm{mg}$, with or without bupivacaine, reduced postoperative pain and morphine consumption following laparoscopic cholecistectomy (Thomas et al., 2006). Studies about epidural methylprednisolone-morphine compositions in orthopaedic knee surgery showed comparable or even superior analgesic effect with bupivacaine-morphine mixture (Golubovska et al., 2007).

We can be quite certain in saying that methylprednisolone suspension has no neurotoxic effect on normal nerves and in the epidural space (Johansson et al., 1995; Delaney et al., 1980).

The aim of our study is to compare pain relief by epidural route of analgesia, using different combinations that include glucocorticoids (methylprednisolone), with habitual composition of bupivacaine-morphine mixture, in regard to analgesic and anti-inflammatory properties of glucocorticoids.

The objectives for our research were:

1) To determine whether perioperative use of epidural methylprednisolone is a sufficient analgesic, when given in small doses of opioids or without them, to achieve an acceptable pain verbal rating score $(0-4)$.

2) To determine whether perioperative use of epidural methylprednisolone can improve endocrine and immune response to surgery.

3) To compare the quality of pain relief and side effects of methylprednisolone-morphine, methylprednisolone-fentanyl combinations and methylprednisolone with bupivacainemorphine combination after knee replacement surgery.

\section{MATERIALS AND METHODS}

The study was performed at the Department of Anaesthesiology and Orthopaedics of the Hospital of Traumatology 
EPIDURAL ANALGESIC COMPOSITIONS IN DIFFERENT TREATMENT GROUPS (I-IV)

\begin{tabular}{|c|c|c|c|c|}
\hline Time & I & II & III & IV \\
\hline End of surgery & $\begin{array}{l}\text { Methylprednisolone } 40 \mathrm{mg} \\
\text { Morphine } 1 \mathrm{mg}\end{array}$ & $\begin{array}{l}\text { Bupivacaine } 25 \mathrm{mg} \\
\text { Morphine } 1 \mathrm{mg}\end{array}$ & $\begin{array}{l}\text { Methylprednisolone } 40 \mathrm{mg} \\
\text { Fentanyl } 0.05 \mathrm{mg}\end{array}$ & Methylprednisolone $40 \mathrm{mg}$ \\
\hline $8 \mathrm{~h}$ after I dose & $\begin{array}{l}\text { Methylprednisolone } 20 \mathrm{mg} \\
\text { Morphine } 0.5 \mathrm{mg}\end{array}$ & $\begin{array}{l}\text { Bupivacaine } 25 \mathrm{mg} \\
\text { Morphine } 0.5 \mathrm{mg}\end{array}$ & $\begin{array}{l}\text { Methylprednisolone } 20 \mathrm{mg} \\
\text { Fentanyl } 0.05 \mathrm{mg}\end{array}$ & Methylprednisolone $20 \mathrm{mg}$ \\
\hline $20 \mathrm{~h}$ after I dose & $\begin{array}{l}\text { Methylprednisolone } 20 \mathrm{mg} \\
\text { Morphine } 0.5 \mathrm{mg}\end{array}$ & $\begin{array}{l}\text { Bupivacaine } 25 \mathrm{mg} \\
\text { Morphine } 0.5 \mathrm{mg}\end{array}$ & $\begin{array}{l}\text { Methylprednisolone } 20 \mathrm{mg} \\
\text { Fentanyl } 0.05 \mathrm{mg}\end{array}$ & Methylprednisolone $20 \mathrm{mg}$ \\
\hline $\begin{array}{l}\text { Total amount } \\
\text { of drugs in } 24 \text { hours }\end{array}$ & $\begin{array}{l}\text { Methylprednisolone } 80 \mathrm{mg} \\
\text { Morphine } 2 \mathrm{mg}\end{array}$ & $\begin{array}{l}\text { Bupivacaine } 75 \mathrm{mg} \\
\text { Morphine } 2 \mathrm{mg}\end{array}$ & $\begin{array}{l}\text { Methylprednisolone } 80 \mathrm{mg} \\
\text { Fentanyl } 0.15 \mathrm{mg}\end{array}$ & Methylprednisolone $80 \mathrm{mg}$ \\
\hline
\end{tabular}

and Orthopaedics. The Ethics Committee of Rīga Stradiňš University approved the study protocols. Informed consent was obtained from all patients. Prospective randomised single-blind trial was conducted from November 2006 to May 2008. A total of 135 patients undergoing knee replacement surgery were included in this study. Patients with diabetes mellitus, infectious problems, rheumatoid arthritis, gastrointestinal ulcerations and those who used glucocorticoids were excluded from the study. Patients were randomly assigned to one of the four study groups. Randomisation was performed in active concurrent control groups.

Patients of Group I received glucocorticoid methylprednisolone succinate and long-acting opioid morphine hydrochloride $(n=33)$.

Patients of Group II received local anaesthetic bupivacaine hydrochloride and morphine hydrochloride $(n=41)$.

Patients of Group III received methylprednisolone succinate and short-acting opioid fentanyl $(\mathrm{n}=31)$.

Group IV received methylprednisolone succinate $(n=30)$.

Combined spinal-epidural anaesthesia (CSEA) was performed to all patients. Spinal bupivacaine $0.5 \%$ was injected intratecally for surgical analgesia. At the end of surgery and during their stay in the postanaesthesia care unit (PACU), patients received different epidural analgesic compositions in accordance with the protocol and time schedules (See Table 1). For each recruited patient in groups I-IV, a trained nurse followed the instructions and prepared the study drugs. All of the study preparations were masked by dilution to the same volume of saline $(10 \mathrm{ml})$. If analgesia was unsatisfactory, the rescue analgesic was bupivacaine $0.5 \% 5 \mathrm{ml}(25 \mathrm{mg})$ epidurally. Rescue medication was given on patient request or if pain exceeded 4 by a 10-point numeral verbal rating scale (NVRS).

Sensory level, motor blockade, pain score, time until the first rescue analgesic, the amount of additional bupivacaine, mean arterial pressure and pulse rate were assessed after introduction for 24 hours. Changes of glucose, C-reactive protein, IL-6 and cortisol were measured before incision and 24 $\mathrm{h}$ after the first epidural injection. Side effects were registered. Patients assessed their experience of postoperative pain at rest by indicating a number on the eleven-point NVRS between the extremes $0 \mathrm{~cm}$-no pain and $10 \mathrm{~cm}-$ the worst pain imaginable at $0,2,4,6,8,12,16,20$ and 24 hours. A patient questionnaire was used to evaluate their satisfaction. Statistical analysis was performed using ANOVA, Students t-test, Wilcoxon Signed Ranks test, Kruskal-Wallis test, Pearson Chi-Square test.

\section{RESULTS}

Six patients were excluded from study due to accidental evacuation of epidural catheter or major motor blockade. Statistical analysis was performed for 129 patients. Patients in all study groups were statistically comparable $(P>0.05)$ (See Table 2).

Although patients in all treatment groups had very acceptable pain scores during the entire period of measurements, the score differed among treatment groups. 24-hour pain intensity was quite similar in all groups, with the lowest score in Group I (see Fig. 1). Regarding the intensity of pain at each observation time, Group I succeeded better than others in the periods just before the first planned epidural injection and during night sleep. Multivariate NVRS at time 3 (6 hours from the first epidural injection) differed among groups: $\mathrm{I}=0.5 \pm 0.6 ; \mathrm{II}=1.2 \pm 0.9 ; \mathrm{III}=1.3 \pm 1.1 ; \mathrm{IV}=1.4$ \pm 0.8 points $(P<0.001)$. Multivariate NVRS at time 5 (which means 12 hours after the first epidural injection): $\mathrm{I}=$ $0.8 \pm 1.1 ; \mathrm{II}=1.0 \pm 1.0 ; \mathrm{III}=1.4 \pm 1.4 ; \mathrm{IV}=1.1 \pm 1.0$ points $(P<0.05)$. The mean pain score for all measurements across times did not differ significantly $(P>0.05)$ between groups: Group I was $0.6 \pm 0.4$, in Group II $-0.8 \pm 0.4$, in Group III $0.9 \pm 0.5$, and in Group IV $0.8 \pm 0.4$. The patients in Group I required significantly less additional bupivacaine administered epidurally. The number of additional

Table 2

DEMOGRAPHIC CHARACTERISTICS OF THE STUDY (GROUPS I-IV)

\begin{tabular}{|c|c|c|c|c|}
\hline Characteristics $\quad$ Groups & I & II & III & IV \\
\hline $\mathrm{N}$ valid & 32 & 39 & 29 & 29 \\
\hline Age (years) & $70.1 \pm 7.9$ & $67.8 \pm 6.8$ & $68.7 \pm 8,1$ & $66.2 \pm 10.1$ \\
\hline $\operatorname{Sex}(m / f)$ & $6 / 26$ & $5 / 34$ & $6 / 23$ & $5 / 24$ \\
\hline $\begin{array}{l}\text { Body-mass } \\
\text { index }(\mathrm{BMI})\left(\mathrm{kg} / \mathrm{m}^{2}\right)\end{array}$ & $29.4 \pm 5.1$ & $32.4 \pm 5.3$ & $30.2 \pm 5.6$ & $30.9 \pm 7.4$ \\
\hline
\end{tabular}

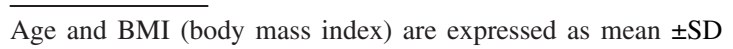




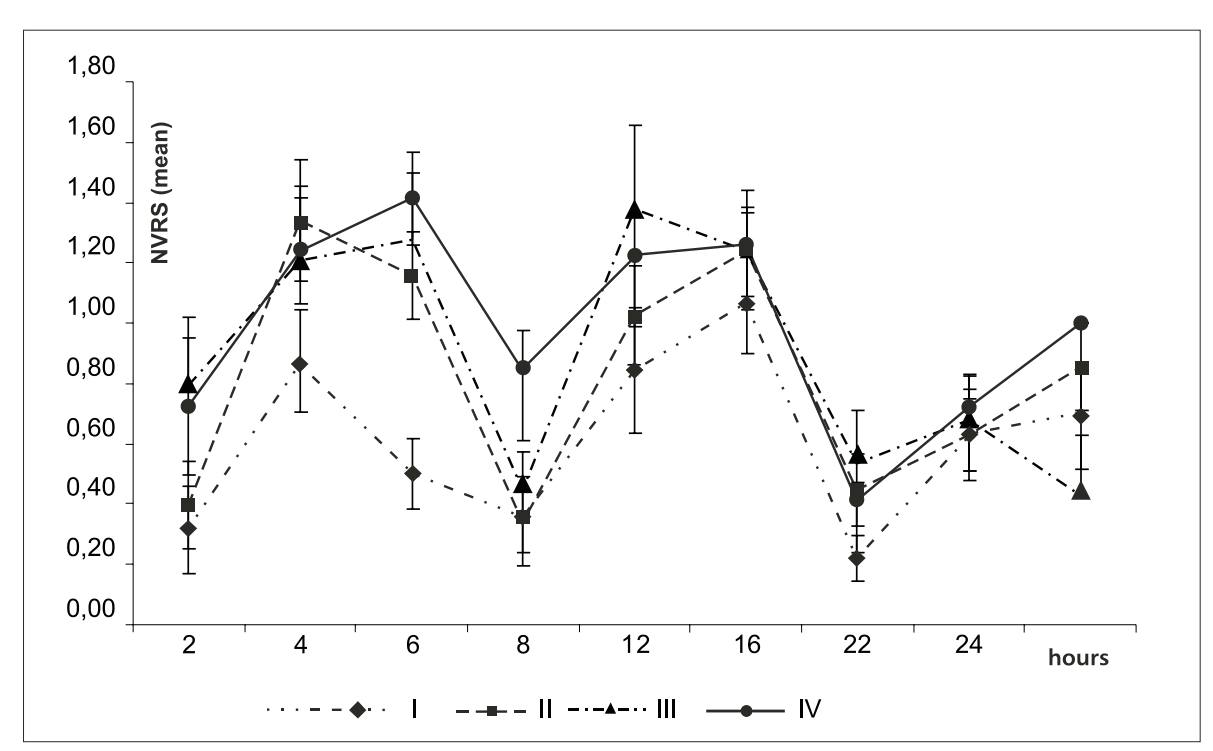

Fig. 1. Pain during the observation period, expressed as numeral verbal rating scale (NVRS) from 0 to 10 . bupivacaine injections (25 $\mathrm{mg}$ ) ranged from 0-2 times (mean $0.66 \pm 0.70$ ) in Group I, 0-4 times in Group II (mean $1.2 \pm 1.0$ ), $0-4$ times in Group III (mean $2.1 \pm 1.2$ ), $0-5$ times in Group IV (mean $2.2 \pm 1.2)(P<0.05)$. During the observation period, 15 patients $(47 \%)$ did not require epidural bupivacaine injections for pain relief in Group I, while only two patients obtained such prolonged pain relief in Groups III and IV $(9.4 \%, 6.2 \%)$. The amount of bupivacaine required for breakthrough pain to reach sufficient analgesia was significantly different in all groups. In Group I, the consumption of additional bupivacaine amid patients who needed it during the first 24 hours postoperatively was $31.0 \pm 10.9 \mathrm{mg}$, in Group II $40.5 \pm 19.4 \mathrm{mg}$, in Group III $58.6 \pm 26.4 \mathrm{mg}$, and in Group IV $57.4 \pm 27.5 \mathrm{mg}$ (mean $\pm \mathrm{SD}, P<0.05$ ) (see Table 3 ). There were no significant differences in time until the first rescue analgesic among groups in patients who needed them.

Not many cardiovascular, neurological and other complications were observed. One patient from Group II died from myocardial infarction on the fifth postoperative day. One patient from Group I developed aseptic inflammation in the knee six months after surgery. The problem was resolved by means of conservative methods. Minor side effects were not statistically different among the groups.

Overall satisfaction rate was very good: $8.5 \pm 1.2$ points. The mean satisfaction rates were: $8.7 \pm 1.0$ in Group I, $8.6 \pm$ 1.3 in Group II, $8.8 \pm 1.0$ in Group III, $8.7 \pm 1.0$ in Group $\mathrm{IV}$ (mean $\pm \mathrm{SD}, P>0.05$ ).
Table 3

CHARACTERISTICS OF POSTOPERATIVE PAIN RELIEF: NUMBER OF RESCUE INJECTIONS AND ADDITIONALLY INJECTED BUPIVACAINE

\begin{tabular}{lcc|c|c}
\hline \multicolumn{1}{c|}{ Groups } & I & II & III & IV \\
\hline $\begin{array}{l}\text { Number of rescue } \\
\text { injections }\end{array}$ & $0.6 \pm 0.7$ & $1.2 \pm 1.0$ & $2.1 \pm 1.2$ & $2.1 \pm 1.2$ \\
$\begin{array}{l}\text { Additional bupivacaine } \\
(\mathrm{mg})\end{array}$ & $30.8 \pm 10.9$ & $40.5 \pm 19.3$ & $58.6 \pm 26.4$ & $57.4 \pm 27.5$
\end{tabular}

Data are presented as mean $\pm \mathrm{SD}$

Regarding anti-inflammatory and hormonal responses to analgesia, we observed a significant difference in IL-6 and CRP postoperative production among the study groups. The increase was similar in the methylprednisolone groups (I, III, IV), while being significantly higher in Group II (see Table 4). The mean IL-6 levels were significantly lower in the methylprednisolone groups compared to bupivacaine group on postoperative day I $(P<0.001)$. There was an increase in the plasma concentration of $\mathrm{C}$-reactive protein in all groups following surgery. The mean $\mathrm{C}$-reactive protein levels were significantly higher in the bupivacaine group compared to methylprednisolone groups on postoperative day I $(P<0.05)$. We performed Pearson's correlation analysis between IL-6 and C-reactive protein levels in the different treatment groups and found significant correlations between IL-6 and C-reactive protein concentrations in Groups I, II and III, but not in Group IV. Cortisol production decreased significantly postoperatively in the methylprednisolone groups $(P<0.05)$ (see Table 4$)$.

Table 4

PRODUCTION OF IL-6, CRP, CORTISOL, AND GLUCOSE IN THE PERIPHERAL BLOOD IN DIFFERENT PAIN TREATMENT GROUPS

\begin{tabular}{c|c|c|c|c|c|c|c|c}
\hline \multirow{2}{*}{ Groups } & \multicolumn{2}{|c|}{ Glucose $\mathrm{mmol} / \mathrm{l}$} & \multicolumn{2}{c|}{ CRP mg/dl } & \multicolumn{2}{c|}{ IL-6 pg/ml } & \multicolumn{2}{c}{ Cortisol $\mu \mathrm{g} / \mathrm{dl}$} \\
\cline { 2 - 9 } & before & after & before & after & before & after & before & after \\
\hline \multirow{2}{*}{ I } & $5.3 \pm 1.0$ & $7.5 \pm 1.3$ & $6.0 \pm 10.5$ & $38.2 \pm 28.1$ & $22.1 \pm 49.9$ & $65.6 \pm 50,9$ & $13.0 \pm 4.4$ & $6.4 \pm 3.4$ \\
II & $5.5 \pm 0.9$ & $7.5 \pm 1.7$ & $4.9 \pm 4.7$ & $71.6 \pm 37.7$ & $14.1 \pm 32.4$ & $267.8 \pm 262$ & $12.8 \pm 3.7$ & $14.3 \pm 6.9$ \\
III & $5.1 \pm 0.6$ & $7.7 \pm 1.8$ & $3.9 \pm 3.9$ & $37 \pm 21.8$ & $9.8 \pm 21.9$ & $61.7 \pm 57.2$ & $13.3 \pm 5.6$ & $5.9 \pm 4.1$ \\
IV & $6.2 \pm 3.8$ & $8.9 \pm 2.6$ & $6.0 \pm 10.3$ & $30.4 \pm 14.9$ & $24.9 \pm 22.6$ & $37.3 \pm 29.6$ & $11.9 \pm 4.9$ & $5.5 \pm 3.9$
\end{tabular}


There was no statistically significant difference in glucose levels before and after surgery among groups, except Group IV (See Table 4).

\section{DISCUSSION}

We compared our study with other outcomes after knee replacement surgery, using epidural analgesia. Muldoon et al. (1998) compared $0.2 \%$ ropivacaine or $0.2 \%$ bupivacaine by epidural infusion for $24 \mathrm{~h}$ after operation. Pain by visual analogue scale (VAS) at rest was low in both groups; the median VAS was $0-13.3 \mathrm{~mm}$ (by $100 \mathrm{~mm}$ VAS) for the ropivacaine group and $0-0.5 \mathrm{~mm}$ for the bupivacaine group. Over $24 \mathrm{~h}$ of infusion, the estimated (ropivacaine-bupivacaine) difference in wound pain at rest was $5.6 \mathrm{~mm}(P<$ $0.05)$ and on passive movement $-11.6 \mathrm{~mm}(P<0.05)$. Himmelseher et al. (2001) added ketamine to epidural injections prior to surgery. After lumbar epidural anaesthesia with ropivacaine $(10 \mathrm{mg} / \mathrm{ml}, 10-20 \mathrm{ml})$, patients received $0.9 \%$ epidural saline or $0.25 \mathrm{mg} / \mathrm{kg}$ epidural $\mathrm{S}(+)$-ketamin $10 \mathrm{~min}$ before surgical incision. During the first $8 \mathrm{~h}$ after surgery, VAS pain rating was similar among groups; nevertheless, the mean VAS for the ketamin group was below 1, whereas for the ropivacaine group-between 1 and 3 at rest. Buvendranan et al. (2006) studied the effects of COX-2 inhibitors on pain management after total knee replacement. CSEA was performed, and the infusion of fentanyl and bupivacaine was started, allowing patients to give themselves bolus doses at their discretion to maintain VAS between 2 and 4 . The research group received additional rofecoxib. Postoperative median pain scores were: $3.5(2.7-4.3)$ in the patient-controlled epidural analgesia group; 2.2 (1.4-3.2) in the rofecoxib group. Pain scores were significantly lower in our study.

Some studies have not found analgesic properties of epidural glucocorticoids.

Lavyne et al. (1992) reported that patients undergoing microdiscectomy, who received epidural methylprednisolone after surgery, did not have reduction of pain compared to the control group. Blanloeil et al. (2001) compared epidural infusion of methylprednisolone $1.5 \mathrm{mg} / \mathrm{kg}$ and placebo after posterolateral thoracotomy. Additional morphine analgesia was administered by intravenous patient-controlled analgesia. There was no significant difference for morphine requirements between the groups. Reikeras et al. (2008) studied glucocorticoids and cytokine production during surgery in orthopaedic patients, administering high doses of methylprednisolone intravenously $(10 \mathrm{mg} / \mathrm{kg})$ and did not find any significant effect of glucocorticoids on postoperative pain. In major abdominal or thoracic surgery, the analgesic and other outcome effects of perioperative glucocorticoids are promising but still debatable; therefore, no definite conclusions can be drawn yet. Studies on major abdominal surgery (Apfel et al., 2004) have not been able to document any definite analgesic effect of glucocorticoids.
The difference in pain among groups did not differ much 24 hours after surgery with clearly better result in Group I. The postoperative period may reflect the interval required for the sensitising effects of surgery to become fixed, or it may reflect peripheral inputs from the operated knee, obscuring the spinal component of nociception in the earlier postsurgical period. In particular, the crucial time interval appears to be from the first minutes to hours after surgery, and then there is a second phase of inflammatory injury with interleukins and acute phase proteins rising up. We cannot decisively state that preventive analgesia was shown. We can only speculate that methylprednisolone blocked pain sensitisation during the entire observation period, while its antinociceptive effects were accomplished by the action of morphine and bupivacaine during the first postoperative hours. On the other hand, pain did not become clinically relevant before patient mobilisation was started. We suggest that the use of small doses of epidural methylprednisolone with morphine before pain begins may decrease injury-induced pain sensitisation, and thus provide better analgesia in the postoperative period than that achieved with a dose of local anaesthetics with morphine in the epidural space.

The concomitant administration of methylprednisolone and morphine results in a synergistic analgesic effect. Sustained postoperative opioid sparring effect and pain relief continuing for three days after one single dose of glucocorticoids (methylprednisolone or dexamethasone) have been reported (Romundstad et al., 2004). A prolonged opioid sparring effect, continuing for at least 72 hours, indicates a prolonged effect of methylprednisolone on postoperative inflammatory pain, which could be explained by the duration of biological anti-inflammatory activity of methylprednisolone-estimated to be about 36 hours after intravenous injection (Holte et al., 2004), although it might be different after epidural injection.

We did not find any similar studies about epidural glucocorticoids and attenuated neuroendocrine and immune response. Reikeras et al. (2008) carried out a study of intravenous high-dose methylprednisolone $(10 \mathrm{mg} / \mathrm{kg})$ in orthopaedic surgery and found that glucocorticoids significantly reduced the increases in IL-6 and C-reactive protein. The imbalance between proinflammatory and anti-inflammatory cytokines determines the development of stress response to surgery and should help the physician to compose a therapeutic strategy. In fact, recent clinical studies have shown that both the initial uncontrolled hyperinflammation and the continued cell-mediated immunosuppression represent primary targets to counteract the post-surgery immune dysfunction (Menger et al., 2004). There are many studies investigating the role of IL-6 in the development of pain, and it is well reviewed that IL- 6 is related to the development of pain and that intrathecal anti-IL-6 antibody will attenuate this reaction (De Leo et al., 1996). Pain is transmitted from the periphery to higher brain areas, from where the pain messages can be either suppressed (analgesia), relayed unaltered, or amplified (hyperalgesia). Pain modulation occurs in the dorsal horns of the spinal cord, where peripheral 
nerves relay sensory information to pain transmission neurons. Both analgesia and hyperalgesia originate at the point where the periphery meets the CNS. Neutralizing IL-6 or changes in the IL- 6 pathway alter the perception of pain. IL-6 induces pain by releasing COX products and inducing arachidonic acid release. This mechanism can be aborted by glucocorticoids. Injecting glucocorticoids epidurally influence IL-6 production both generally and locally; notably, only very small amounts are needed for good effect. Pearson's correlation test did not show any statistically significant correlation between IL- 6 concentration and the mean pain intensity, which might be explained by wrong timing. In any case, it is difficult to interpret the absence of correlation between IL-6 level and intensity of pain from one measurement. We chose a 24-hour time interval because it was described as the peak level of IL-6 and C-reactive protein after major orthopaedic surgery (both hip and knee) in some literature (Hall et al., 2000) and major orthopaedic surgery of spine in others (Reikeras et al., 2008).

In conclusion:

1) Epidural analgesia produced reliable pain relief in all study groups. Patients were highly satisfied with knee surgery performed under epidural analgesia. However, significantly better results were achieved when using the combination of methylprednisolone and morphine (Group I).

2) Epidural methylprednisolone $80 \mathrm{mg} / 24 \mathrm{~h}$ is effective as a part of multimodal preventive postoperative analgesia after major joint replacement surgery. Compared to habitual local anaesthetics and opioid mixture, it shows a similar or even better analgesic effect (in combination with morphine).

3) Adding fentanyl in epidural mixtures had only a minor effect on postoperative analgesia after knee replacement surgery with no significant difference from that achieved with addition of saline.

4) Epidural methylprednisolone has marked morphine sparring effect.

5) Epidural methylprednisolone has marked anti-inflammatory and immunomodulatory potential. The altered IL-6, C-reactive protein and cortisol values among the groups may be a direct effect of methylprednisolone, considering that the same type of surgery-i.e. producing similar degrees of tissue damage-and anaesthetic regimens were used.

\section{REFERENCES}

Apfel, C.C., Korttila, K., Abdalla, M., Sessler, D.I., Roewer, N. (2004). A factorial trial of six interventions for the prevention of postoperative nausea and vomiting. N. Engl. J. Med., 350, 2441-2451.

Barnes, P. (1998). Anti-inflammatory actions of glucocorticoids: Molecular mechanisms. Cli. Sci ., 94, 557-572.

Bisgaard, T., Klarskov, B., Kehlet, H., Rosenberg, J. (2003). Preoperative dexamethasone improves surgical outcome after laparoscopic cholecystectomy. A randomized double-blind placebo-controlled trial. Ann. Sur., 238, 651-660.
Buvanendran, A., Tuman, K. J., McCoy, D. D. (2006). Anesthetic techniques for minimally invasive total knee arthroplasty. J. Knee. Surg., 19, 133-136.

Carette, S., Leclaire, R., Marcoux, S., Morin, F., Blaise, G. A., St-Pierre, A., Truchon, R., Parent, F., Levésque, J., Bergeron, V., Montminy, P., Blanchette, C. (1997). Epidural corticosteroid injections for sciatica due to herniated nucleus pulposus. N. Engl. J. Med., 336(23), 1634-1640.

Delaney, T. J., Rowlingson, J. C., Carron, H., Butler, A. (1980). Epidural steroid effect on nerves and meninges. Anesth. Analg., 59, 610-614.

Di, S., Malcher-Lopes, R., Marcheselli, V. L., Bazan, N. G., Tasker, J. G. (2005). Rapid glucocorticoid-mediated endocannabinoid release and opposing regulation of glutamate and gamma-aminobutyric acid inputs to hypothalamic magnocellular neurons. Endocrinology, 146, 4292-4301.

Falkenstein, E., Tillmann, H. C., Christ, M., Feuring, M., Wehling, M. (2000). Multiple actions of steroid hormones-a focus on rapid, nongenomic effects. Pharmacol. Rev., 52, 513-556.

Ferreira, S.H., Cunha, F.Q., Lorenzetti, F.B. (1997). Role of lipocertin-1 in the anti-hyperalgesic action of dexamethasone. Brit. J. Pharm., 121, 883-888.

Gilron, I. (2004). Corticosteroids in postoperative pain management: Future research directions for a multifaceted therapy. Acta. Anaesth. Scand., 48, 1221-1222.

Glasser, R.S., Knego, R.S., Delashaw, J.B., Fessler, R.G. (1993). The perioperative use of corticosteroids and bupivacaine in the management of lumbar disc disease. J. Neurosurg., 78, 383-387.

Golubovska, I., Studers, P., Jaunalksne, I., Vanags, I. (2007). Effects of postoperative epidural analgesia on immune response to surgery. Acta Med. Lith., 10, 14-16.

Golubovska, I., Studers, P., Vanags I. (2007). Pain relief after joint replacement surgery. RSU zinātnisko rakstu krājums. 2006. gada medicīnas nozares pētnieciskā darba publikācijas, pp. 129.-33.

Hafezi-Moghadam, A., Simoncin, I.T., Yang, Z. (2002). Acute cardiovascular protective effects of corticosteroids are mediated by non-transcriptional activation of endothelial nitric oxide synthase. Nat. Med., 8, 473-479.

Hall, G.M., Peerbhoy, D., Shenkin, A., Parker, C.J., Salmon, P. (2000). Hip and knee arthroplasty: A comparison and the endocrine, metabolic and inflammatory responses. Clin. Sc., 98(1), 71-79.

Himmelseher, S., Ziegler-Pithamitsis, D., Argiriadou, H., Martin, J., Jelen-Esselborn, S., Kochs, E. (2001). Small-dose S(+)-ketamine reduces postoperative pain when applied with ropivacaine in epidural anesthesia for total knee arthroplasty. Anesth. Analg., 92, 1290.

Holte, K., Kehlet, H. (2002). Perioperative single-dose glucocorticoid administration: Pathophysiologic effects and clinical implications. J. Am. Coll. Surg., 195, 694-712.

Johansson, A., Dahlin, L., Kerns, J. M. (1995). Long-term local corticosteroid application does not influence nerve transmission or structure. Acta. Anaesth. Scand., 39, 364-369.

Joos, S. (1993). The use of glucocorticoids and non-steroidal anti-inflammatory drugs for preventive postsurgical pain relief. Bailliere's Clinical Anaesthesiology, 7(3), 318-356.

Kehlet, H. (2007). Glucocorticoids for peri-operative analgesia: How far are we from general recommendations? Acta. Anaesth. Scand., 51(9), 1133-1135.

Langmayr, J. J., Obwegeser, A. A., Schwarz, A. B., Laimer, I., Ulmer, H., Ortler, M. (1995). Intrathecal steroids reduce pain after lumbar disc surgery: A double-blind, placebo-controlled prospective study. Pain, 62, 357-361.

Lavyne, M. H., Bilsky, M. H. (1992). Epidural steroids, postoperative morbidity, and recovery in patients undergoing microsurgical lumbar discectomy. J. Neurosurg., 77, 90 -95.

Manchikanti, L. (2002). Role of neuraxial steroids in interventional pain management. Pain Phys., 5, 182-199.

Maillefert, J. F., Aho, S., Huguenin, M. C. (1995). Systemic effects of epidural dexamethasone injections. Rev. Rhum. Eng. Ed ., 62, 429-432. 
Marinanageli, F., Ciccoli, A., Donatelli, F., Paladini, A., Varassi, H. (2002). Uso degli steroidi per via spinale ed epidurale. Minerva Anestez., 68, $613-620$

McNeill, T. W., Andersson, G. B., Schell, B., Sinkora, B., Nelson, J., Lavender, S. A. (1995). Epidural administration of methylprednisolone and morphine for pain after a spinal operation. A randomized, prospective, comparative study. J. Bone. Joint. Surg., 77, 1814-1818.

Menger, M.D., Vollmar, B. (2004). Surgical trauma: Hyperinflammation versus immunosuppression? Langenbecks Arch. Surg., 389, 475-484.

Muldoon, T., Milligan, K., Quinn, P. (1998). Comparison between extradural infusion of ropivacaine or bupivacaine for the prevention of postoperative pain after total knee arthroplasty. BJA, 80, 680-681.

Nagelschmidt, M., Fu, Z. X., Saag, S., Dimmeler, S., Neugebauer, E. (1999). Preoperative high dose methprednisolone improves patients outcome after abdominal surgery. Eur. J. Surg., 165(10), 971-978.

Ontjes, D. A. (1995). Adrenal corticosteroids, corticotropin releasing hormone, adrenoconticotropin and antiadrenal drugs. In Munson, P.L. (ed.). Principles of Pharmacology, Basic Concepts and Clinical Applications. New York, NY: Chapman \& Hall, pp. 749-787.

Reikerås, O., Helle, A., Krohn, C. D., Brox, J. I. (2008). Cytokine responses to glucocorticoids and surgery. Eur. J. Trauma. Emerg. Surg., 2, 141-148.

Rhen. T., Cidlowski, J. A. (2005). Antiinflammatory action of glucocorticoids-new mechanisms for old drugs. N. Engl. J. Med., 353, 1711-1723.

Romundstad, L., Breivik, H., Niemi, G., Stubhaug, A. (2004). Methylprednisolone intravenously 1 day after surgery has sustained analgesic and opioid-sparing effects. Acta Anaesth. Scand., 48, 1223-1231.

Romundstad, L., Breivik, H., Roald, H., Skollberg, K., Haugen, T., Narum, J., Stubhaug, A. (2006). Methylprednisolone reduces pain, emesis and fatigue after breast augmentation surgery: A single-dose, randomized, parallel-group study with methylprednisolone $125 \mathrm{mg}$, Parecoxib $40 \mathrm{mg}$, and placebo. Anest. Analg., 102, 418-425.
Sauerland, S., Nagelschmidt, M., Mallmann, P., Neugebauer, E.A. (2000) Risks and benefits of preoperative high dose methylprednisolone in surgical patients: A systematic review. Drug Saf., 23(5), 449-461.

Schimmer, B.P., Parker, K.L. (1996). Adrenocorticotropic hormone: Adrenocortical steroids and their synthetic analogs; inhibitors of the synthesis and actions of adrenocortical hormones. In Goodman and Gilman's The Pharmacological Basis of Therapeutics, 9th ed, Hardman J.G., Limbird, L.E., Molinoff, P.B., Ruddon, R.W., Goodman Gilman A. (eds). McGraw-Hill, New York, pp. 1459-1485.

Schulze, S., Andersen, J., Overgaard, H. (1998). Effect of prednisolone on the systemic response and wound healing after colonic surgery. Arch. Surg., 132, 129-135.

Schulze, S., Sommer, P., Bigler, D. (1992). Effect of combined prednisolone, epidural analgesia, and indomethacin on the systemic response after colonic surgery. Arch. Surg., 127, 325-331.

Skjelbred, P., Løkken, P. (1982). Reduction of pain and swelling by a corticosteroid injected 3 hours after surgery. Eur. J. Clin. Pharm., 23(2), $141-146$.

Stubhaug, A., Romunstad, L., Kaasa, T., Breivik, H. (2007). Methylprednisolone and ketorolac rapidly reduce hyperalgesia around a skin burn injury and increase pressure pain thresholds Acta Anaesth. Scand., 51, 1138-1146.

Thomas, S., Beevi, S. (2006). Epidural dexamethasone reduces postoperative pain and analgesic requirements. Can. J. Anesth., 59(9), 899-905.

Wang, Y. L., Tan, P. P., Yang, C. H., Tsai, S. C., Chung, H. S. (1997) Epidural dexamethasone reduces the incidence of backache after lumbar epidural anesthesia. Anesth. Analg., 84, 376-378.

Watanabe, S., Bruera, E. (1994). Corticosteroids as adjuvant analgesics. J. Pain. Symptom. Managem., 9, 442-445.

Yeager, M. P., Guyre, P. M., Munck, A.U. (2004). Glucocorticoid regulation of the inflammatory response to injury. Acta. Anaesth. Scand., 48(7), 799-813.

Received 3 October 2008

\section{DAŽĀDU PĒCOPERĀCIJAS EPIDURĀLO ANALGĒZIJAS KOMPOZĪCIJU IETEKME UZ ATSĀPINĀŠANU UN ATBILDI ĶIRURĢISKAJAM STRESAM PĒC CEL,A ENDOPROTEZĒŠANAS OPERĀCIJĀM}

Neraugoties uz sasniegumiem pēdējos gados, akūtās pēcoperācijas sāpes ir visbiežākā pacientu sūdzība pēc kirurǵiskas iejaukšanās, taču tās ir potenciāli visvairāk ietekmējamas perioperatīvajā periodā. Mūsu pētījuma mērkisis bija salīdzināt epidurālo atsāpināšanu pēc ceḷa endoprotezēšanas operācijām, izmantojot dažādas medikamentu kompozīcijas. Mēs salīdzinājām grupas, kuru kompozīcijas ietvēra glikokortikoīdu metilprednizolonu kombinācijās ar dažādiem opiōidiem un bez tiem ar ierasto lokālā anestētiķa bupivakaīna un morfīna kompozīciju un pētījām to ietekmi uz pēcoperācijas atsāpināšanu un neiroendokrīno un imūno atbildi kirurǵiskajam stresam. Pētỉjumu pabeidza 129 pacienti četrās terapijas grupās. I grupas pacienti epidurāli san̄ēma glikokortikoīdu metilprednizolona sukcinātu un ilgstošas darbības opioīdu morfīna hidrohlorīdu, II grupas pacienti sanēema lokālo anestētiḳi bupivakaīna hidrohlorīdu un morfīna hidrohlorīdu, III grupas pacienti saņēma metilprednizolona sukcinātu un fentanīlu, IV grupas pacienti saņēma metilprednizolona sukcinātu. Atsāpināšana bija ḷoti laba visās terapijas grupās, bet metilprednizolona-morfīna grupā mēs ieguvām statistiski ievērojami labākus rezultātus. Epidurālais metilprednizolons devā $80 \mathrm{mg} / \mathrm{dn}$ atklājās kā efektīva multimodālās preventīvās atsāpināšanas sastāvdaḷa pēc ceḷa endoprotezēšanas operācijām. Salīdzinot ar ierasto bupivakaīna-morfīna kompozīciju, ir pierādīts līdzīgs vai pat vēl labāks efekts. Epidurālais metilprednizolons ir arī pierādījis savas imūnmodulējošās un pretiekaisuma īpašības, ietekmējot akūtās pēcoperācijas iekaisīgās fāzes mediatorus - interleikīnu-6 un C-reaktīvo olbaltumu un samazinot stresa hormona kortizola līmeni pēcoperācijas periodā. Šì pētījuma novitāte ir glikokortikoīdu epidurālā izmantošana tieši akūto pēcoperācijas sāpju samazināšanai ikdienas darbā. Attīstot pētījumus par metilprednizolona pretiekaisuma un imūnmodulējošām īpašībām, mēs vēlētos uzlabot pacientu rehabilitāciju pēcoperācijas periodā. 